\section{Obushenko T., Tolstopalova N., Baranuk N.}

\title{
INVESTIGATION OF SOLVENT SUBLATION OF COBALT IONS FROM WATER SOLUTIONS
}

Об’єктом дослідження є флотоєкстракиія в системі кобальт-додецилсульфат натрію. Дослідження флотоекстракційного очищення стічних вод від іонів важких металів малочисельні і носять розрізнений та несистематичний характер. Тому дослідження процесу флотоекстракцї як методу очищення стічних вод від важких металів на прикладі іонів кобальту (II) є перспективним. У роботі досліджено модельні водні розчини кобальту концентрації 20 мг/дм³ з використанням аніонної поверхнево-активної речовини (ПАР) додецилсульфату натрію та ізоамілового спирту в якості органічної фази. Отримано рачіональні умови процесу: $p H$ 10, молярне співвідношення $\mathrm{Co}^{2+}:$ ПАР $=1: 2$, витрата повітря $45 \mathrm{~cm}^{3} / x в$, температура $20{ }^{\circ} \mathrm{C}$,

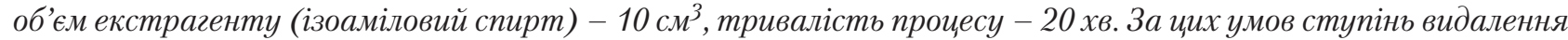
іонів кобальту в ізоаміловий спирт склала $85 \%$. Процес описується кінетичним рівнянням першого порядку. Розраховано константи швидкості процесу. Важливість проведеного дослідження підкреслюється тим, що флотоекстракція має ряд особливостей та переваг. Зокрема, можливість багатократного концентрування іонів забрудника у невеликих об’ємах органічного розчинника та можливість його подальшої регенерачії. При цьому використовується значно менша кількість органічного розчинника та процес не лімітується константою розподілу (у порівнянні з методом екстракцї). Флотоекстракція також характеризується відсутністю піни (у порівнянні з методом флотащіі) та відсутністю великих кількостей вологого осаду (у порівнянні з реагентним методом). Запропонований у роботі метод забезпечує достатній рівень очищення стічних вод від іонів металів, а також може бути застосований в системах локального очищення стоків з наступним поверненням води у технологічний прочес. Це забезпечить зниження витрат на споживання водних ресурсів, скидання стічних вод у водні об'єкти, а також обмежить потрапляння шкідливих речовин у навколишнє середовище. Крім того, особливості флотоекстракцї̈ дозволяють регенерувати екстрагент та ПАР.

Ключові слова: видалення іонів кобальту, флотоекстракційне очищення стічних вод, додецилсульфат натрію, ізоаміловий спирт.

\section{Introduction}

Existing technologies for the purification of waste water from heavy metal ions are imperfect. This necessitates the search and implementation of alternative methods aimed at the complete purification of wastewater from pollutants of various nature. To achieve a more complete purification of wastewater from heavy metal ions, it is proposed to apply the solvent sublation method, which has several advantages compared with other known flotation methods [1,2]. The uniqueness of this process is the method of extracting sublate substances (sublate) by concentrating it in the layer of organic liquid - extractant - on the surface of the aqueous phase [3-5]. Sublate is capable of either forming a suspension, is retained due to wetting, or dissolved in the organic phase [6, 7]. Equilibrium in this process is established at the interface of the aqueous-organic phase. The amount of collected sublate in the organic layer does not depend on its volume, since equilibrium is not established in the entire system. The passage of sublate into the organic layer from the phase boundary is a process due to the movement of a stream of gas bubbles. This is not a spontaneous distribution process, which is associated with the relative solubility of sublate in two phases. Despite all the advantages of solvent sublation, to date, this method of purification has not yet received wide industrial application. However, there are numerous experimental results of studies of the regularities and optimal parameters of this process, which substantiate the expediency of the expanded use of solvent sublation [8,9]. Therefore, an experimental study of the nature of the effect on the extraction efficiency of the following parameters is relevant: the nature of the extractant, the $\mathrm{pH}$ of the medium, the duration of solvent sublation, the value of the molar ratio of surfactants (surface-active substances): Metal, gas consumption, temperature of the aqueous phase. Thus, the object of research is solvent sublation in the cobalt- sodium dodecyl sulphate system. And the aim of research is studying the solvent sublation, as a method of purifying waste water from heavy metals by the example of cobalt (II) ions.

\section{Methods of research}

To study the solvent sublation process, a cylindrical glass column with a diameter of $35 \mathrm{~mm}$ was used. Air was supplied by a compressor to the bottom of the column, flow was controlled by a rotameter. Air dispersion was carried out through a Schott filter. The concentration of cobalt ions in model solutions was $20 \mathrm{mg} / \mathrm{dm}^{3}$. The volume of the solution is $200 \mathrm{~cm}^{3}$, the volume of the extractant (isoamyl alcohol) is $10 \mathrm{~cm}^{3}$. The solvent sublation process was carried out to establish a constant residual concentration of cobalt ions, which was determined by the photometric method on a Portlab 501 single beam scanning spectrophotometer (United Kingdom) [10]. The $\mathrm{pH}$ adjustment was carried out with solutions of $\mathrm{NaOH}$ and $\mathrm{HCl}$ with a concentration 
of $0.1 \mathrm{~mol} / \mathrm{dm}^{3}$ (pH of aqueous solutions was measured using a $\mathrm{pH}$-meter $\mathrm{pH}-150 \mathrm{MI}$ (Russia)). The efficiency of the solvent sublation process was evaluated by the extraction degree of cobalt ions.

\section{Research results and discussion}

Fig. 1 shows the dependence of the extraction degree of $\mathrm{Co}^{2+}$ ions on the molar ratio of $\mathrm{Co}^{2+}$ : surfactant.

According to the results (Fig. 1), in the range of molar ratios of $\mathrm{Co}^{2+}$ : surfactant from 1:0.5 to 1:1.5, the degree of cobalt extraction is not enough. This is due to the fact that this amount of surfactant is not enough to fully bind cobalt to sublate. When using sodium dodecyl sulfate, the highest extraction degree of cobalt ions is $84.46 \%$ with a ratio of $\mathrm{Co}^{2+}$ : surfactant $=1: 2$. Further, there is a decrease in the efficiency of solvent sublation, because with an increase in the amount of surfactant in solution $\left(\mathrm{Co}^{2+}\right.$ : surfactant $=1: 2.5$ and so on $)$ in the aqueous phase, an excess amount of surfactant anions appears.

The dependence of the $\mathrm{Co}^{2+}$ extraction degree on the $\mathrm{pH}$ of the solution. Hydrogen index is corrected in the range of 3-11 (Fig. 2).

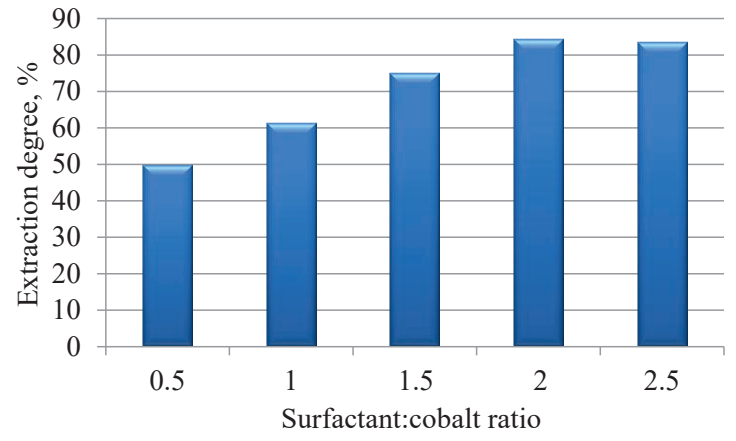

Fig. 1. Dependence of cobalt (II) ions extraction degree on the surfactant:cobalt molar ratio

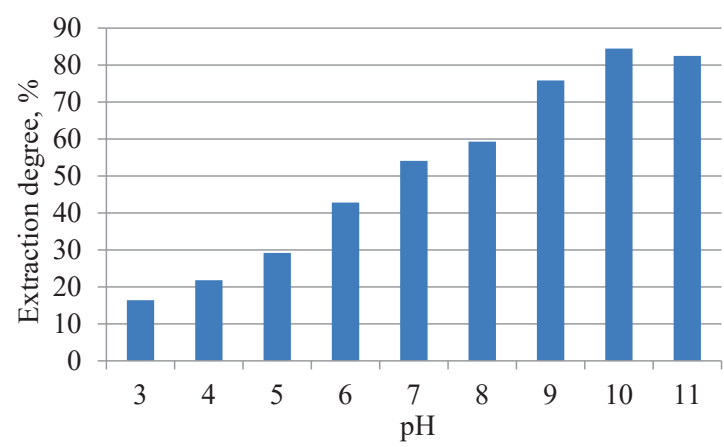

Fig. 2. Dependence of cobalt (II) ions extraction degree on $\mathrm{pH}$

It is better to extract $\mathrm{Co}^{2+}$ at $\mathrm{pH} 10$. At this $\mathrm{pH}$ cobalt sublate is in the form of a neutral hydroxide molecule, which is hydrophobizated by surfactant.

Fig. 3 shows the dependence of the $\mathrm{Co}^{2+}$ extraction degree on the duration of the solvent sublation process with a different $\mathrm{Co}^{2+}$ :surfactant molar ratio. The process was carried out for 25 minutes. Sampling for analysis was performed every 5 minutes.

The rational process duration was 20 minutes. The increase in the solvent sublation duration is almost no effect on the $\mathrm{Co}^{2+}$ extraction degree.
Air consumption is an important factor during the solvent sublation process (Fig. 4).

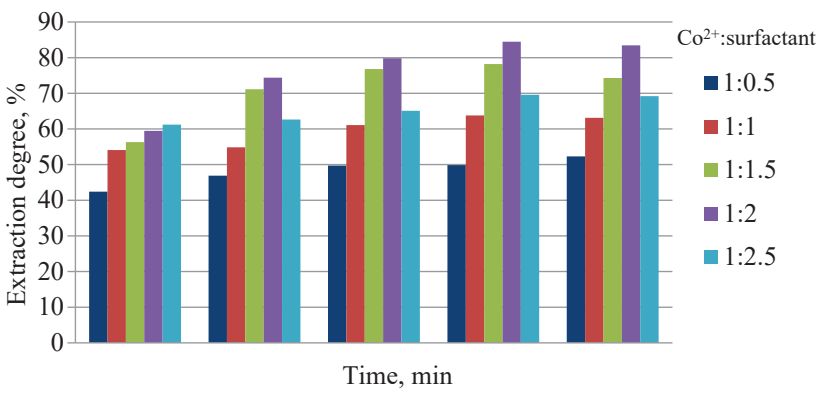

Fig. 3. Dependence of cobalt (II) ions extraction degree on the duration of the process at a different molar ratio

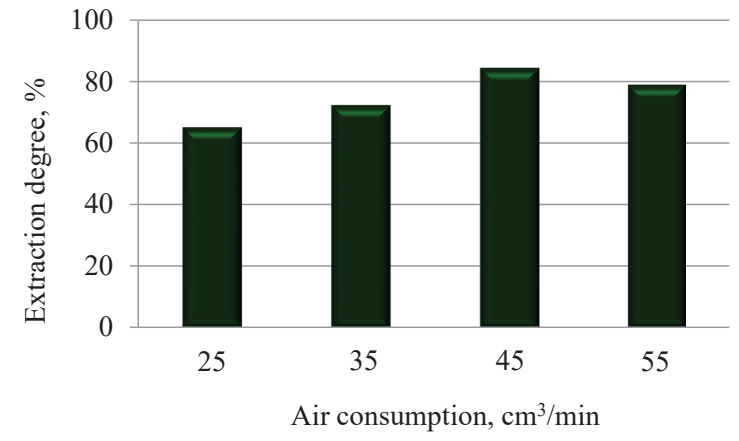

Fig. 4. Dependence of cobalt (II) ions extraction degree from the air consumption

The extraction of cobalt ions is only $72.4 \%$ with air consumption in the range of $25-35 \mathrm{~cm}^{3} / \mathrm{min}$, since this number of air bubbles is not enough to completely transfer pollutants into the organic phase. The highest degree of extraction of cobalt ions is observed at an air consumption of $45 \mathrm{~cm}^{3} / \mathrm{min}$. At large values, there is a slight decrease in the extraction degree. This is due to the fact that with an increase in the rate of movement of air bubbles, a partial violation of the integrity of the organic layer occurs and, as a result, part of the sublate returns to the aqueous phase.

Fig. 5 shows the dependences of the $\mathrm{Co}^{2+}$ ions extraction degree on the temperature of the aqueous phase. Studies were conducted in the range of $10-40{ }^{\circ} \mathrm{C}$. Solvent sublation parameters: process duration $-20 \mathrm{~min}$, molar ratio of $\mathrm{Co}^{2+}$ : surfactant $-1: 2, \mathrm{pH} 10$.

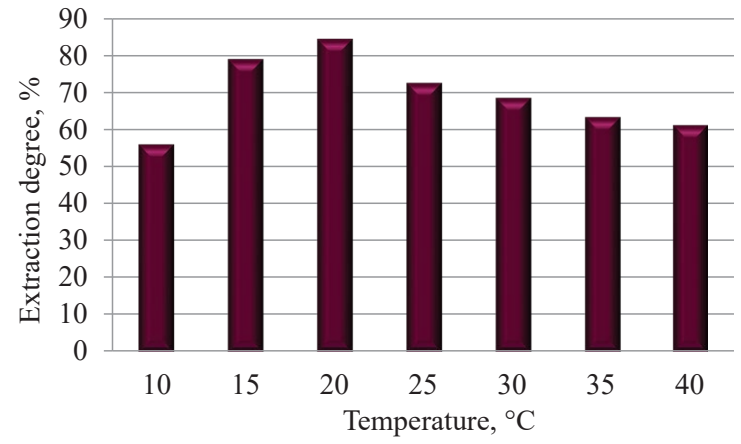

Fig. 5. Dependence of cobalt (II) ions extraction degree on the temperature of the aqueous phase

The process takes place in the adsorption mechanism and, accordingly, with increasing temperature there is 
a decrease in the efficiency of the process, explains the decrease in the extraction degree of cobalt. Fig. 6 shows the graphical dependences of the natural logarithm of the cobalt ion concentration on the solvent sublation duration. This is the first order of reaction, because the graphical dependence is straightforward.

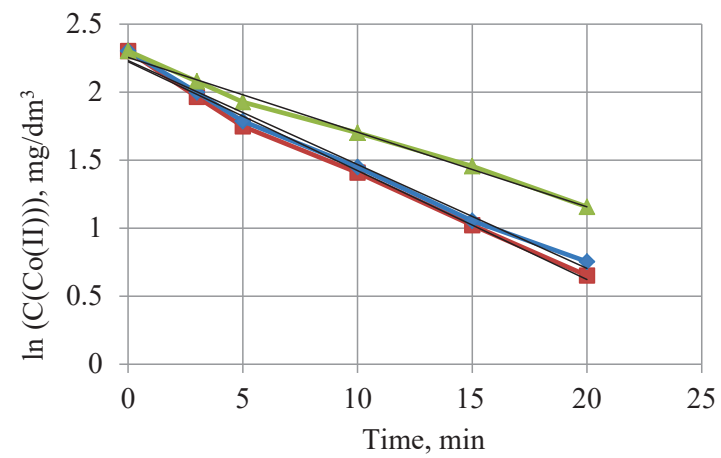

$\neg-293 R^{2}=0.993 \leadsto 298 R^{2}=0.9925 \leftarrow 303 R^{2}=0.9934$

Fig. 6. Dependence of the natural logarithm of the concentration of cobalt ions on the solvent sublation duration at various temperatures

To calculate the reaction rate constant, the formula (for the first order reaction) is used:

$$
k=\frac{1}{\tau} \cdot \ln \frac{C_{0}}{C_{\tau}},
$$

where $\tau$ - solvent sublation duration; $C_{0}$ and $C_{\tau}-$ the initial and current concentrations of cobalt ions.

The results of the calculations of the constant are given in Table 1.

Table 1

Reaction rate constants of the solvent sublation

\begin{tabular}{|c|c|c|c|}
\hline Temperature, $\mathrm{K}$ & 293 & 298 & 303 \\
\hline$k, \mathrm{~min}^{-1}$ & 0.096 & 0.090 & 0.065 \\
\hline
\end{tabular}

The first order of the process and the value of the process rate constant indicate the course of solvent sublation in the stationary diffusion mode, when the limiting stage is the diffusion of particles extracted from the surface of gas bubbles [11].

\section{Conclusions}

The extraction of cobalt ions with a concentration of $20 \mathrm{mg} / \mathrm{dm}^{3}$ from aqueous solutions in the cobalt - sodium dodecyl sulphate system by solvent sublation is studied. Based on experimental studies, the optimal process conditions are obtained: the volume of extractant (isoamyl alcohol) $-10 \mathrm{~cm}^{3}$, the ratio of cobalt ions in the surfactant $-1: 2$, $\mathrm{pH} 10$, air consumption $-45 \mathrm{~cm}^{3} / \mathrm{min}$, the process duration $-20 \mathrm{~min}$, phase temperature $-20^{\circ} \mathrm{C}$. Under these conditions, the extraction degree of cobalt ions is about $85 \%$. The solvent sublation process of cobalt ions is described by a kinetic equation of the first order, the velocity constants are calculated. The proposed method of solvent sublation purification can be an alternative and innovative method of wastewater purification before discharge into reservoirs or in the case of their return to the circulating water supply.

\section{References}

1. Lu Y., Zhu X. Solvent Sublation: Theory and Application // Separation and Purification Methods. 2001. Vol. 30, Issue 2. P. 157-189. doi: http://doi.org/10.1081/spm-100108158

2. Bi P., Dong H., Dong J. The recent progress of solvent sublation // Journal of Chromatography A. 2010. Vol. 1217, Issue 16. P. 2716-2725. doi: http://doi.org/10.1016/j.chroma.2009.11.020

3. Teoretychni zasady ta praktychne zastosuvannia flotoekstraktsii: ohliad / Astrelin I. M., Obushenko T. I., Tolstopalova N. M., Tarhonska O. O. // Voda i vodoochysni tekhnolohii. 2013. Isseu 3. P. 3-23.

4. Studies on Solvent Sublation of Trace Heavy Metals by Continuous Flow System as Ternary Complexes of 1,10-Phenanthroline and Thiocyanate Ion / Kim Y., Shin J., Choi Y., Lee W. // Bulletin of the Korean Chemical Society. 2003. Vol. 24, Issue 12. P. 1775-1780. doi: http://doi.org/10.5012/bkcs.2003.24.12.1775

5. Study of a mathematical model of metal ion complexes in solvent sublation / Lu Y. J., Liu J. H., Xiong Y., Zhu X. H. // Journal of Colloid and Interface Science. 2003. Vol. 263, Issue 1. P. 261-269. doi: http://doi.org/10.1016/s0021-9797(03)00192-9

6. Determination of zinc and lead in water samples by solvent sublation using ion pairing of metal-naphthoate complexes and tetra-n-butylammonium ion / Kim Y., Choi Y., Lee W., Lee Y. // Bulletin of the Korean Chemical Society. 2001. Issue 22. P. 821-826.

7. Solvent sublation trace noble metals by formation of metal complexes with 2-mercaptobenzothiazole / Kim Y., Shin J., Lee W., Lee Y. // Bulletin of the Korean Chemical Society. 2001. Issue 22. P. 19-24.

8. Perlova O. V., Sazonova V. F. Flotoekstrakcionnoe izvlechenie soedinenii lantana iz razbavlennyh vodnyh rastvorov // Visnik ONU. 2012. Vol. 17, Issue 1 (41). P. 52-57.

9. Wastewater Treatment from Toxic Metals by Flotoextraction / Obushenko T. I., Astrelin I. M., Tolstopalova N. M., Varbanets M. A., Kondratenko T. A. // Journal of Water Chemistry and Technology. 2008. Vol. 30, Issue 4. P. 241-245. doi: http:// doi.org/10.3103/s1063455x08040073

10. Analitychna khimiia pryrodnoho seredovyshcha: textbook / Nabyvanets B. Y., Sukhan V. V., Kalabina L. V. Kyiv: Lybid, 1996. $304 \mathrm{p}$

11. Lobacheva O. L., Chirkst D. E., Dzhevaga N. V. Solvent sublation of yttrium ions from dilute aqueous solutions by use of sodium dodecyl sulfate // Russian Journal of Applied Chemistry. 2012. Vol. 85, Issue 8. P. 1153-1156. doi: http://doi.org/10.1134/ s1070427212080022

Obushenko Tetjana, Senior Lecturer, Department of Inorganic Substances, Water Purification and General Chemical Technology, National Technical University of Ukraine «Igor Sikorsky Kyiv Polytechnic Institute», Ukraine, e-mail: tio1963@gmail.com, ORCID: http://orcid.org/0000-0003-0731-0370

Tolstopalova Nataliia, PhD, Associate Professor, Department of Inorganic Substances, Water Purification and General Chemical Technology, National Technical University of Ukraine «Igor Sikorsky Kyiv Polytechnic Institute», Ukraine, e-mail: tio1963@gmail.com, ORCID: http://orcid.org/0000-0002-7240-5344

Baranuk Nadiya, Department of Inorganic Substances, Water Purification and General Chemical Technology, National Technical University of Ukraine «Igor Sikorsky Kyiv Polytechnic Institute», Ukraine, e-mail: kiissld@gmail.com, ORCID: http://orcid.org/00000002-2288-1377 